\title{
IRISH FILM AND TELEVISION - 2019
}

\author{
THE YEAR IN REVIEW \\ Roddy Flynn, Tony Tracy (eds.)
}

Copyright (c) 2020 by the authors. This text may be archived and redistributed both in electronic form and in hard copy, provided that the author and journal are properly cited and no fee is charged for access.

Introduction.

Roddy Flynn.

Getting on with the Extra Ordinary

Extra Ordinary (Mike Ahern and Enda Loughman, 2019)

Harvey O’Brien....

Ordinary Love (Lisa Barros D'Sa and Glenn Leyburn, 2019)

Tony Tracy.

Postcard from the edge

Losing Alaska (Tom Burke, 2018)

David Robbins

The Hole in the Ground (Lee Cronin, 2019)

Denis Murphy

Dark Lies the Island (Ian Fitzgibbon, 2019)

Siobhán Kane....

The Curious Works of Roger Doyle (Brian Lally, 2018)

Stephanie McBride.

Memory as Trauma

Cellar Door (Viko Nikci, 2018)

Emma Radley

Dublin Murders (BBC/RTE/Starz, 2019)

Sheamus Sweeney. .324 


\title{
Introduction.
}

\author{
Roddy Flynn
}

Sometimes, even an annual review feels like it might be too frequent, especially if its subject is an industry wherein the activity often fails to resolve itself within neat 12 months intervals. The policies put in place to incentivise production and the broader development of the screen sector in Ireland operate across five year horizons. Even for individual productions, the gap between a greenlight for production and the actual appearance of the text via whatever primary platform may span several years. (This is particularly true of labour intensive sectors like animation. Cartoon Saloon's Nora Toomey is currently working on a feature version of Ruth Stiles Gannett's classic 1948 children's book My Father's Dragon which was commissioned in 2018 but which will not see the light of day until 2021).

Despite this one can tentatively point to "certain tendencies", some novel and still emerging, some entrenching well-established patterns and some - most notably the performance of Irish screen texts in their domestic market - downright worrying. The effects of a marked heating up of the streamer wars on the other side of the Atlantic clearly works to the benefit of a local industry which, pace the Irish government's 2018 Audiovisual Action Plan is seeking to present itself as "a global hub for the production of Film, TV Drama and Animation". The fall-out from these wars - an at least short-term upsurge in demand for content to fill the silos of new players hoping to distinguish themselves in an increasingly crowded marketplace - reinforces the post-2005 trend whereby the highest profile productions in the Irish screen production ecology have primarily been commissions for US cable channels including Showtime (The Tudors, Penny Dreadful), Starz (Camelot), the History Channel (Vikings) and Syfy (Night Flyers).

The relative ease with which Ireland has established itself as key element of the international division of screen labour (albeit this is the result of active policy and industry efforts to attract such productions) is shadowed by the implications for the Irish film and television sectors exposure to international competition at the point of consumption. In marked contrast to recent years where local heroes - Mrs Brown's Boys (2014), The Young Offenders (2016), Black '47 (2018) - achieved significant domestic audiences, 2019 saw indigenous production struggled to make an impact in a cinema market dominated by US franchise behemoths. Just 10 films accounted for 38\% of total Irish box office in 2019: three from the Marvel Cinematic Universe, four additions to the Disney animation franchise (including live action remakes), the unexpected global hit Joker and the big screen reboot of Downton Abbey. Only one - Rise of the Skywalker - could be regarded as even tangentially connected to Ireland given its use of the Skelligs as a location. The issue is less acute on the small screen: new drama on RTE and Virgin Media found audiences but notably often did so with content increasingly - and manifestly - designed with an international market in mind, an ambition usually reflected in the involvement of production entities and funders from beyond Ireland. This may be trivial but it may also discourage work perceived as "difficult" for international audiences.

If ever there was a sector which exemplified the disruptive potential of the digital network economy (think Uber, Airbnb and Amazon) it is the arrival of OTT ("Over The Top") or streaming services into a small-screen market long dominated by $20^{\text {th }}$ century industrial-scale broadcasting behemoths. Subscription-based revenue models directly commodifying audiences have transformed the economics of an industry long reliant on either advertising 
revenue, public support through broadcast licence fee revenues or, in the case of most European public service broadcasters, a combination of both.

If this has already been the case over the past decade, emerging industrial configurations in the US are clearly set to further upset the apple cart. Having effectively dominated (indeed largely created) the global market for streaming services since 2010, Netflix is suddenly facing a plethora of challenges from OTT services offered by legacy television companies (CBS's "All Access", Disney's "Disney+" and - from April 2020 NBC's "Peacock"), slightly newer media companies (HBO's "HBO Max" debuting in May 2020) and digital native players such Amazon's Prime Video and Apple+, as the post-Steve Jobs era tech company finally decided to invest some serious capital into its "Apple TV +" service.

The scale of the potential outlay on content production across these firms is staggering. Although those services rooted in legacy production will to a large extent cannibalise their existing libraries to fill out their content roster, the newer players are increasingly looking to rapidly acquire their own directly-owned content to obviate the possibility that rights holders will retrieve their content back as they also move into the OTT market. (Netflix has already experienced a haemorrhage of Disney content - Marvel, Star Wars, Animation - as the latter's "Disney+" service came on stream.) Netflix's total content budget in 2013 as House of Cards appeared for the first time was around \$2.3bn, the bulk of which was spent on external acquisitions. By 2019, that figure had leapt to a reported $\$ 15 \mathrm{bn}$ most of which is being spent on the direct production of some 300 film and television shows from countries around the world. For its part Apple's 2017 announcement that it was ramping up its own content production with a war-chest of $\$ 1 \mathrm{bn}$ initially seemed impressive but the sudden arrival of much broader competition in the intervening two years saw that figure leap to \$6bn spent on high profile Emmy-friendly content such as the Morning Show. Amazon too has massively upped its game, matching Apple's investment by 2019 and pumping circa $\$ 1 \mathrm{bn}$ into its five-season adaptation of Tolkien's Lord of The Rings (due to begin streaming in 2021). Taken in aggregate then, the streamer wars have conjured something like $\$ 35 \mathrm{bn}$ for investment in content. This figure, equivalent to $12 \%$ of Irish GNP in 2019, is critical to understanding the current political economy of Irish screen production. In an age where runaway production is taken for granted (the single most successful global television show of the past decade - Game of Thrones - which was shot in Northern Ireland, Spain, Croatia, Iceland and Morocco) it is scarcely any wonder that owners of production facilities including Ardmore, Troy and Ashford Studios have been licking their lips and expanding their facilities in anticipation that some of the streamer bounty would find its way to these shores.

And it has. The aforementioned Cartoon Saloon project My Father's Dragon was commissioned by Netflix, which also briefly diverted the Vanessa Hudgens 2019 vehicle The Knight Before Christmas from its Ontario location for a two-day sojourn in the gothic Charleville Castle outside Tullamore. In September 2019, principal photography began at Ardmore Studios on the Netflix-commissioned Fate: The Winx Saga, a live-action adaptation of the RAI Italy/Nickelodeon animated series about a group of, wait for it, crime-busting fairies. Perhaps most significantly in November 2019, Netflix ordered production of 24 episodes of Valhalla, advancing by 100 years the setting of the History Channel's Vikings (which saw its sixth and final series shot in 2018).

However, even this was dwarfed by the July 2019 announcement Troy Studios would play host to a $€ 45 \mathrm{~m}$ 10-part adaptation of Isaac Asimov's Foundation sci-fi sequence. Produced for Apple TV by Skydance Television in partnership with local production company Wild Atlantic Pictures, Foundation became, at a stroke, the single largest single production ever shot in Ireland, directly employing 500 people (even if production was suspended in mid-March in response to the Covid-19 outbreak). 
Between 2008 and 2011, the money spent on labour by indigenous television production and incoming projects was roughly equivalent, with each contributing about $€ 15 \mathrm{~m}$ in expenditure. However, the labour-value of incoming television productions since 2016 has exploded, reaching $€ 99 \mathrm{~m}$ in 2017 as compared with the $€ 5.5 \mathrm{~m}$ spent on employment in local productions. TV drama, driven by the presence of international productions $i s$ now the core of the industry, accounting for more than half of the total $€ 291 \mathrm{~m}$ Irish expenditure across film, animation, documentary and television in 2017. Incoming television productions alone accounted for $€ 156 \mathrm{~m}$ of that. In other words, even before the Audiovisual Action Plan declared its global hub ambitions for the Irish screen production sector, it's goals had arguably already been partially achieved with more than $80 \%$ of Irish production expenditure in 2017 being sourced from outside Ireland.

The question is what this leaves at the local level and, more specifically, what did it leave in 2019. On the big screen, although not constituting the total released output of Irish cinema in 2019, 23 feature films and feature docs with some Screen Ireland support made their way into cinema between January and December. Admittedly, at a textual level audiences might have been hard-pressed to recognise some these as local texts since, in keeping with the ongoing outward look of indigenous production, so many are set elsewhere (and indeed often have even limited Irish personnel involvement). Audiences flocked to Element Pictures The Favourite, the awards haul of which, drove shy of $€ 1 \mathrm{~m}$ worth of admissions in Ireland. However, local audiences proved immune to the allure of even those international films with (unlike the Yorgos Lanthimos-directed Oscar- bait) actually had Irish directors. Neil Jordan's New York-set Greta, a two-hander with Isabelle Huppert and Chloe Grace Moretz made only a muted impact on its Irish release despite major distribution support. For its part John Butler's unexpected follow-up to Handsome Devil, a likeable odd couple comedy called Papa Chulo set in sunny California disappeared without trace on release here. (It did however, enjoy something of an afterlife on Netflix and, piquantly, offered Irish viewers the peculiarly arresting about seeing the words "Screen Ireland in association with RTÉ" superimposed over a Los Angeles vista). Ivan Kavanagh's, Never Grow Old, a leftfield western featuring Emile Hirsch and John Cusack suffered a similar fate on its August 2019 release. Given it's (Irish) west coast setting, (and not notwithstanding the central casting of Stephen Dorff and Melissa George) David Gleeson's psychological horrorthemed Don't Go with its overt debt to Nicolas Roeg Don't Look Now (and even David Keating's Wake Wood) might have anticipated a better fate but despite prominence of local talent (notably Simon Delaney and Aoibheann Ginnity), at best lukewarm reviews consigned it to oblivion (and, in all likelihood, ultimately to a streamer near you).

Perhaps most disappointingly, the more unproblematically Irish films -, Viko Nikci's impressive Cellar Door (reviewed elsewhere by Emma Bracken), Ian FitzGibbon's black comedy Dark Lies The Island, Carmel Winters' boxing drama Float Like A Butterfly, Hugh O'Connor's likeable comedy Metal Heart (from a script by Skippy Dies author Paul Murray), and Shelly Love's A Bump Along the Way (an unplanned pregnancy drama starring Bronagh Gallagher) - all failed to breach the top ten in the week of their release despite support from distributors familiar with the Irish market (Eclipse and Wild Card) and generally positive reviews. Even those that did - however - briefly penetrate the public consciousness can hardly be said to have done so in any spectacular fashion. Aoife Crehan's macabre comedic feature debut The Last Right released just before Christmas 2019 looked like it might have legs, taking $€ 20 \mathrm{k}$ and reaching number five in the top ten on its first week of release (doubtless aided by a significant push from its mini-major distributor eOne). However, it appeared to flounder somewhat thereafter. Ordinary Love, (reviewed by Tony Tracy) a reflective study of middle-aged love under duress was a double hander in two senses, with two directors - the duo Lisa Barros D'Sa and Glenn Leyburn - and two sensitive 
performances from Liam Neeson and Lesley Manville. Yet it struggled to make $€ 20 \mathrm{k}$ at the box office. Another directorial two-hander, the Mike Ahern-Enda Loughman-directed Extra Ordinary (here reviewed by Harvey O'Brien) with a winning central performance from standup Maeve Higgins, took $€ 50 \mathrm{k}$ despite offering an often hilarious take on the Irish horror genre. Indeed, just one film, Lee Cronin's The Hole in the Ground (of which Denis Murphy offers a review and production history elsewhere in this year's review) took enough at the box office - $€ 150 \mathrm{k}$ - to allow it match the revenues of the fifth most successful Irish film of 2019.

The net impact of all this in financial terms is not yet $100 \%$ clear. Since 2010, Irish films have accounted for anything from less than $1 \%$ of total local box office to - driven in part by Brendan O'Carroll's Mrs Brown's Boys D'Movie - up to 7\% in 2014. The combined box office of Irish films in 2018 - the year of Black 47, Damo and Ivor and Dublin Oldschool - was just shy of $€ 3 \mathrm{~m}$ or about $2.5 \%$ of all revenues. Although official figures for 2019 have not yet been released, overall attendance fell $4 \%$ to $15.1 \mathrm{~m}$ admissions, suggesting that the post-recession recovery of 2015-17 would not be sustained. However, it is also clear that Irish films in 2019 almost certainly failed to account for even $1 \%$ of their own box office. (It is already clear at time of writing, as public events in Ireland are curtailed in response to the Covid-19 pandemic that 2020 attendance figures will be even worse than previous years.)

Accounting for this disappointing performance is necessarily speculative. The Hole in the Ground relative success may owe something to its generic - horror - nature and, at a stretch, whatever star power lead actor Seana Kerslake exerts. Surveying the releases above it is hard not to notice the prevalence of genre work amongst the fiction releases: three horrors and a western. We have speculated in these pages before as to the operation of a political economy which perhaps tacitly encourages such genre-based production. As Emma Bracken's perceptive reading of Cellar Door argues, there is no contradiction between genre and a local address. Indeed it may be that Cellar Door director Nikci's part-outsider status (originally from Kosovo, Viko has lived in Ireland for two decades and is married to Jim Sheridan's niece) permits him the distance to interpret the operation of historical institutional abuse in Ireland in a manner a native (an "insider") might not achieve. However, it is equally arguable that although The Hole in the Ground's adherence to genre conventions made it a relatively straightforward sell to international funding agencies, the condition attached to such funding dilute its cultural specificity. If, as Denis Murphy's review notes, the involvement of Finnish funding is reflected in the presence of cast credits like "Kati Outinen: Noreen O'Brady" one consequence is that film occasionally feels "displaced" or least uncertain of its setting. (Those who have watched The Hole in the Ground will know that Outinen's is a non-speaking role and thus the national origin of the actor is arguably relatively trivial. But it may also raise the question of the whether the role is silent precisely because the actor's natural accent was not Irish.)

Although space does not permit extensive consideration of the documentary form this year, we should also note that 10 Screen Ireland feature docs were released this year and that here too the outward gaze and concerns with matters beyond these shores was evident in titles such as Gaza, Losing Alaska (herein reviewed by David Robbins) but also in Johnny Gogan's Prisoners of the Moon (about Nazi rocket scientist Arthur Rudolph), Seamus Murphy's journey with English music icon PJ Harvey A Dog Called Money, UK filmmaker Kim Longinotto's truly extraordinary tale of photojournalist Letizia Battaglia Shooting the Mafia and another addition to Paul Duane's international CV, the often hilarious Best Before Death on musician and art terrorist Bill Drummond (he of - formerly - The KLF). Indeed just three of the feature documentaries - Frank Shouldice's eccentric tale of septuagenarian Cavan brothers with aviator ambitions The Man Who Wanted to Fly, another addition to the growing canon of architecture-themed documentaries, Marcus Robinson's An Engineer Imagines and the harrowing Land Without God, a study of institutional abuse co-directed by actor (and 
survivor) Mannix Flynn, Lotta Petronella and Maedhbh McMahon - directly addressed Irish themes at all.

The final area to consider then is the health of Irish television drama production. RTE's ongoing financial travails have clearly curtailed the scope for costly drama on the national broadcaster. Although Amy Huberman's Finding Joy was recommissioned, to date Irish audiences exposure to new material from RTE - soap opera aside - was limited to Dublin Murders, (here reviewed by Sheamus Sweeney) a somewhat awkward melding of two storylines from the crime novels of author Tana French. Though apparently sufficiently satisfied with the performance to contemplate a second series, reviews were muted and notwithstanding an impressive cast (Sarah Greene and Killian Scott amongst others) and strong production values, RTE struggled to surpass audiences in excess of 200,000, well below the 300,000 plus who tuned to watch the channel's 2018 drama showcase Taken Down. More is promised from RTE in 2020 - Dead Still a Victorian era set murder mystery built around Michael Smiley's photographer protagonist and, almost inevitably, an adaptation of Sally Rooney's critically-acclaimed international best-seller Normal People directed by Lenny Abrahamson and Hettie MacDonald - but the cupboard seems dispiritingly bare at present.

Indeed, upstart competitor Virgin Media has threatened to upstage RTEs' drama output in the past 12 months. Though released without any of the fanfare surrounding Dublin Murders (the profile of which was enhanced by its broadcast on both stations funding it RTE and the BBC) Mark "Cardboard Gangsters" O'Connor's Darklands, which traced the domestic impact of criminal activity within a single family built around the parallel lives of MMA fighter Damien and his small-time felon brother Wesley. Sombre, low-key (and presumably relatively low budget) Darklands managed to explore the impact of a criminal existence in a manner which avoided the histrionics Love/Hate increasingly resorted to as it moved to its conclusion.

Darklands was also unusual in that - almost uniquely - it appeared to be the only Irish drama (again, excepting soaps) that was made last year with Irish audiences squarely in its sights. Though Dublin Murders and Normal People are unquestionably Irish stories, it is striking that both are based on pre-sold properties -best-selling novels - with built-in international audiences. Whether this guarantees actual sales remains to be seen, although it is notable the Virgin Media apparently secured sales in 65 territories for the first season of the Adrian Dunbar starrer Blood, more or less guaranteeing the production of the second series which went out on Irish screens in February 2020. In a neat circumnavigation, Blood was coproduced by Acorn TV (as was RTE's Dead Still) a production company seeking to make inroads into the US market as a second-tier streaming service based around British material (or at least material with a UK-feel). That such collaboration is apparently critical for Irish material to be commissioned at all should give us pause for thought.

Roddy Flynn is an Associate Professor at the School of Communications, Dublin City University. He is co-editor (with Tony Tracy) of the Annual Review of Irish Film and Television for Estudios Irlandeses and, again with Tony Tracy, author of the second edition of the Historical Dictionary of Irish Cinema (Rowman and Littlefield, 2019).

roderick.flynn@dcu.ie 
Getting on with the Extra Ordinary

Extra Ordinary (Mike Ahern and Enda Loughman, 2019)

\author{
Harvey O'Brien
}

As Ireland becomes more comfortable with its place in a transnational cinematic landscape, Irish horror cinema has been determinedly staying on trend. Recent films like The Devil's Doorway (Aislinn Clarke, 2019) and The Hole in the Ground (Lee Cronin, 2019) have learned the lessons of the East Asian slow creep, the indie indignation of Jordan Peele and Jennifer Kent, and how to use the Irish environment to exploit the natural affinity with post apocalypticism and folk horror. Not that a global outlook is a bad thing, but Extra Ordinary (Mike Ahern and Enda Loughman, 2019) is a determinedly parochial film that wears its localism not so much proudly on its sleeve, because that would be having notions, but casually like an old jumper.

The film is a horror comedy, blending gore and parody with something altogether more distinctly and identifiably provincial, because even parody is a bit hifalutin, like. It stars a reassuringly rural-accented Maeve Higgins as Rose, a small town driving instructor with a dark past... or, well, listen, not so much dark as, sure, not worth talking about really. No, yeah, she's a psychic medium, see, and her father was a very famous paranormal researcher who vanished in mysterious and unearthly circumstances years ago, only she'd really prefer not to talk about it. In fact her voice mail message makes it clear that if you're calling about "the other thing", she doesn't do that anymore, but she's very happy to give you driving lessons and she'll even bring a snack if you want one. Thing is, she does see dead people, and haunted toasters, green bins, and other fairly unglamorous manifestations of otherworldliness, even though she'd much rather not because, you know, she really can't be dealing with that sort of thing.

Higgins is so perfect at the heart of the film that it would be easy to assume it was entirely conceived around her particular style, an extension of her stand up or and sketch comedy. She has even played the psychic role before as a character on Naked Camera (200507) where she masqueraded as a spirit medium looking to get insurance cover for her spectral visitors from unsuspecting brokerage firms. A faux American accent added a ring of absurd credibility to that persona for sketch purposes and likely threw off her victims, but Higgins has demonstrably always been able to play straight in the midst of the preposterous. She also seems able to present satire without humiliation and self-deprecation without selfcongratulation (the "nudge-nudge" curse of the prankster). It is that essential quality of gentleness that lightens the heart of Extra Ordinary, which has some stuff in it that might not otherwise be to all tastes. Higgins and Damien Fox did assist in the writing of the film, but Ahern and Loughman conceived of Extra Ordinary as a consciously unique and particularly Irish film "the opposite of Ghostbusters" in which the banal and the wondrous rub elbows and never bat an eyelid, as when an Irish person sees a celebrity in the street and merely nods. Their hope was for "a film only we could make" but with a "heart that hopefully becomes universal when other people watch it."

The antagonist of the piece is the amusingly-named Christian Winter (Will Forte) a washed-up singer whose one-hit-wonder "Cosmic Woman" riffs on motifs from Chris De Burgh, including a la-la-la chorus and sci-fi synths. He now lives in the local big house (of course) and has made a pact with a demon with a taste for virgins (not goats - some demons are into that, but not all of them, you see). Meanwhile his bored wife Claudia (Claudia O'Doherty) is having an awful time ordering a good Chinese while waiting for riches to ensue from all this Diabolism. An added gag is the very blandness of Winter's star persona. 
Supporting a bad wig and lush moustache, Forte is playing Seventies smooth as incongruously as is entirely appropriate, a caricature in stark contrast to the usual countercultural heavy metal diabolist seen tongue-in-cheek as recently as in Jason Lei Howden's Deathgasm (2015, NZ).

The central dynamic of the film between the extraordinary and the extra ordinary is encapsulated in the difficulties faced by widower Martin Martin (Barry Ward), which triggers the plot. He is trying to get on with his life while still under the thumb of his dead wife, Bonnie, who is still watching over him and their daughter Sarah (Emma Coleman) not from a respectful distance in a celestial sanctuary, but right in the house with them. She makes her presence known by throwing things at Martin's head when household details don't match her standards. Considerably more malevolent than Blithe Spirit's Elvira, Bonnie eventually makes a cameo appearance of sorts when she possesses Martin, giving Ward a chance to do a series of comic personality shifts complete with distinctive facial expressions, a border countys accent, and an omnipresent fag-end that simply appears whenever Bonnie manifests. Martin deals with the ongoing post-mortem domestic disturbance as any typical Irish person would, with a shrug and "sure, what can I do?" attitude. The more assertive Sarah has other ideas and urges her Dad to contact Rose before, in the way of these things, becoming Christian Winter's next target.

Extra Ordinary is humorous but not apologetic about having thematic preoccupations. The film is about lives lived in denial, about obsessions with the past and the importance not so much of forgetting what has gone before as dealing with it and moving on. Rose can't let go of her father, Martin can't let go of Bonnie, Christian can't let go of his ego. All of them must ultimately do so, a realisation triggered by their encounters with one another. Even Bonnie has to learn to release her grip on her erstwhile family and recognise her time has passed. This is an apt enough metaphor for the path of Irish genre cinema, so often secretly shame-faced under the stern ideological gaze of First Wave film and academic approbation.

The film is set in a vaguely defined early 2000s Ireland, which allows a lo-fi aesthetic (clam phones and answering machines) to add to the sense of pleasing parochialism and to paper over the cracks in what might be otherwise expected to be a bit more woke. It is reminiscent of Moone Boy (2012-15) or even Derry Girls (2018 - ) in this feeling, and in its deployment of the comparatively recent past as a space for comedic retrospection, though its representation of small town Ireland is considerably more regressive and less pointedly satirical. It has a henpecked husband, a shrewish Aussie wife, pinafore-clad housewives (Derry Girls' Siobhan McSweeney has a small role as "Boring Noreen") and other assorted rural types: all the trappings of an era in humour probably entirely alien to the average millennial. Being set just after the turn of the century might, in that sense, be part of its armour. It is, after all, a world that is consciously and specifically trapped by (damaging) legacies of the past. It also has a go at representational forms of a bygone era, such as Rose's father's ultra-cheesy VHS lecture series on the paranormal that she uses for reference and the ongoing twee Irish television broadcasts seen in the background (hmm... is that bit really so retro?).

Rose is essentially the post-teenage sad single girl, unglamorous and unloved, bouncing on her yoga ball in her tights while eating yoghurt, and on a trajectory to inevitable romantic rescue. Given such a familiar trope from the romantic comedy (a genre itself on a post-millennial downswing), it shouldn't surprise us to find it running through what is at least partly a parody of one genre allied with some of the tics of another. However, unflappable (mainly) and nonplussed in her physicality and temperament, Higgins makes Rose both dimensional and anchoring. As Rose uses her gifts to help Martin and Sarah, she is also true to that part of herself she has attempted to close off. In so being she becomes less moribund and more fully alive. Rose's quest to shed her past and the legacy of her father comes with an 
inherent sense of loss, but there remains that sense that her essential nature makes it less about rescue (not least because she is the actual agent of rescue in the narrative - saving Martin and Sarah) and more about self-realisation and the discovery of a path from (figurative and literal) death to (hopeful and renewed) life. Higgins imbues Rose with a strength grounded not in sensational revelation, excessive vulnerability, or outward sexual availability, but rather in that core ethos of the quotidian that is funny precisely because it is so, well, "ordinary".

It's not that comedy hasn't been tried before, or been used as an ironic mask in Irish film. In fact, the first Irish horror to attract any kind of international notice - the Derek Landy-penned Boy Eats Girl (Stephen Bradley, 2005) - was ahead of the global curve as a rom-zom-com with Samantha Mumba front and centre of a new Irish ethnicity. Paddy Breathnach's Shrooms (2007) went for a kind of shaggy-dog resolution that either played as cynical or subversive depending on how you rolled with it. Grabbers (John Wright, 2012) put the piss-up in piss-take in a canny nod to the ongoing global categorisation of Irish parochialism as centring on alcohol, here weaponised against alcohol-allergic sea monsters. Neil Jordan, of course, jumped the gun entirely way back with High Spirits (1988) though the lyrical whimsy he was hoping for in trafficking between the worlds of the living and the dead was lost somewhere between the star powers Steve Guttenberg and Peter O'Toole and the accents of Daryl Hannah and Liam Neeson.

In Extra Ordinary, the parodic elements don't undermine the film's generic base. It's something in the tone, where that gentle parochialism seems to reassure us that statements of the obvious are assumed to be obvious, but that that's okay. There are jokes about The Exorcist (William Friedkin, 1973) and of course heavy nods in the direction of The Sixth Sense (M. Night Shyalaman, 1999), but the film also mercilessly skewers a particular strand of 1970s diabolist tales that fuelled the culture of the Satanic Panic. The nature of evil as wilful cruelty grounded in selfishness and self-absorption is firmly spelled out, and the villain's self-delusion is shown to be more complete and intractable than those exhibited by Rose and Martin. We're invited to laugh at things that don't change. There's also a lot of bad taste sexual humour (including bestiality gags) and lashings of comical gore right from the get-go, as well as repeated regurgitation scenes (gathering ectoplasm, you see) which eventually drive Martin to cry out "does it have to be so unnecessarily gross?" mid-vomit, and the climax of the film turns on a gag about virginity that you either take as you find it or which will finally push you over the edge into joyless disapproval.

There was a time not that long ago where the appropriateness and applicability of this film as an exhibition of the ethos of an Irish cinema would have been sombrely debated. But by 2020 Irish genre films have begun to display edges and contours and even a saggy midsection that they might just be comfortable enough with to not be quite so uptight about it. Extra Ordinary premiered at SXSW in 2019 and after an Autumn release in Europe hit general distribution in the US in March 2020. Judging by the reactions recorded online by Wildcard Distribution following its screenings at SXSW in 2019, the blogosphere seems to have got the joke, and, unsurprisingly, hailed Maeve Higgins at the heart of it, just being like herself, like.

Harvey O'Brien is currently Head of Film Studies at University College Dublin. He the author of numerous articles and books chapters, relating to film and is a frequent contributor to Irish radio on the subject. He has also authored Action Movies: The Cinema of Striking Back (Columbia University Press, 2012), The Real Ireland: The Evolution of Ireland in Documentary Film (Manchester, 2004) and co-edited Keeping it Real: Irish Film and Television (Wallflower, 2004).

harvey.obrien@ucd.ie 
Ordinary Love (Lisa Barros D'Sa and Glenn Leyburn, 2019)

\section{Tony Tracy}

Ordinary Love marks the third film and something of a departure for Northern Irish directing duo by Lisa Barros D'Sa and Glenn Leyburn who came to attention with Cherrybomb (2009) - a rauchous coming-of-age drama set in contemporary Belfast - and Good Vibrations (2012) - set around the eponymous Belfast record shop and its notorious proprietor Terry Hooley during the Troubled 1970s. Both met with critical success with the later especially praised for its warmth and energy in spite of being set during "the grimmest period in the grimmest city in the western world" (Donald Clarke). For their third film, they have again stay focused on character and Northern Irish settings in an artfully realized story of mid-life cancer and coupledom.

The story is simple: a middle-aged couple Tom and Joan (Liam Neeson, Leslie Manville) is shunted from the familiar grooves of their quiet existence following her diagnosis with breast cancer. The film follows the ups and downs of Joan's subsequent struggle - medical and emotional - as she embarks on an extended process of treatment and eventual recovery. Along this journey their relationship is tested, they encounter another couple in comparatively worse circumstances than their own and recall the loss of their daughter in sudden circumstances some years earlier. While the film's conclusion brings mixed emotions, the filmmakers avoid any easy conclusions about cancer or its meaning, preferring to quietly return its characters to everyday life.

The screenplay for Ordinary Love developed from the personal experiences of Belfast screenwriter Owen McCafferty and his wife. McCafferty is a well established playwrite whose previous drama Unfaithful (2014) also focused on the pressures of mid-life marriage though - as the title suggests - in more contentious circumstances. That play forgrounded themes of disappointment and frustration and was judged to offer "an understated fulness in its portrait of a marriage gone stale" during its short run at the 2014 Edinburgh Theatre Festival. While Ordinary Love revisits similar territory with comparable methods McCafferty's friend, renowned soundtrack composer David Holmes (Ocean's 11, Hunger) saw the cinematic potential of this deeply personal experience and had the reputation and experience push it forward. (Holmes is the film's producer and composer of its restrained electronic soundtrack). Building on his talents and themes in theatre, the film thus represents a considerable scaling up for McCafferty in terms of casting, production values and audience reach while still remaining true to its NI origins, with the distribution rights being picked up by US indie distributor Focus Features/Universal Pictures even before it was finished. ${ }^{1}$ Neeson and Manville came on board based on an early draft and their casting were central to such transatlantic interest. The screenplay is both understated and profound, qualities embued by the central performances and every element of the production.

Essentially a two-handed drama, the Tom and Joan are clearly defined but entirely interdependent; it is impossible - for us and them - to imagine their story as anything but collective. The film's co-directors have an unusual and similarly mutual creative relationship, planning in detail months before rehearsals and shooting begins and then working collaboratively on set. While Barros comes from a writing background and concentrates on casting and the actors, Leyburn previously worked as a graphic designer and tends to the more technical aspects of production. The film benefits in evident ways from this combination: a modulated narrative which is performed with nuance and restraint and framed within a modernist visual sensibility, with minimal camera movement, artful compositions and a striking use of light and colour. 
Indeed, so careful is the film's production design that while the film's two central settings - the house and the hospital - are shot on location in and around Belfast, they are imbued with formal aesthetics beyond their naturalistic function, simultaneously recognisable and vividly expressive. While the hospital is all blues and whites, evoking a cooly clinical and at times futuristic environment (compounsed by a gliding camera, scanning technologies and eerily de-personalized operating theatres), the house is muted and melancholic; its interior all browns and greens, its inhabitants more often sillouteted against the light outside than fully lit within. The cool mise-en-scène of this setting in particular (the film is shot in widescreen, an unusual choice for a domestic drama) evokes recent arthouse films such as A Single Man (Ford, 2009) or Caché (Haneke, 2005), also stories of mid-life crisis which foreground the home as a site of instability and/or threat. Along with the cancer diagnosis, a clue to this sombre tonality is provided by a single photo on the mantlepiece of a young woman in graduation robes. We subsequently learn that this is their daughter Debbie who died suddently some eyars ago in unspecificed circumstances. The house, and the lives of her parents have remained suspended in the amber of grief ever since. (At one point Joan reports that Tom simply "stopped" following her death).

Positioned between these past and future settings, the couple travel to and from the hospital, increasingly anxious and bickering, submitting to tests and treatments, hopeful that the threat will recind. On each occasion the directors offer us shots of the interior of the intermittently abandoned house; a half opened door, an empty bedroom, a dining table. Portents of mortality that evoke Philip Larkin: "Home is so sad. It stays as it was left / Shaped to the comfort of the last to go / As if to win them back ....". For now however they have each other and it is the dynamicism of their love that the film follows with emphatic tenderness and truthfulness.

Neeson and Manvill's Tom and Joan conjure a seasoned and quietly joyful love. There are few scenes of domesticity but many of intimacy, which the film makers and performers work to establish as having evolved over a long time, through a range of verbal and gestural acts. Indeed the film is particuarly successful at bringing this intimacy to an almost ritulaized level, where words and actions are less acts of creation governed by functionality than repetition and recreation. Their roles and scripts are familiar. When at the outset Joan asks Tom to check if there is a lump on her breast he casually remarks "lumps and bumbs, you're not getting any younger kid", a petname he uses affectionately and repeatedly. Elsewhere Joan responds with playful put-downs: "Tom for once in your life can you try to be normal". When her hair beings to fall out, Tom remains in his teasing-affectionate mode: "You look beautiful - but then I never really liked your hair to begin with". Gestures have a similarly engrained feel. The film opens and closes with a tracking shot of a walk along a seafront promenade with the couple walking hand in hand silouetted against the seascape/skyline. When they reach a particular point, Tom unconsiously reaches out to a tree trunk and gently swings them around to walk back. Their actions and interaction are observed, not heard with the clear sense that they have done this on many occassions. The repeating of this scene at the film's conclusion is particuarly effective, with Tom putting an unconsiously caring and protective hand on Joan's back as they walk away from the camera, into the future.

With the cancer diagnosis and treatment their easy banter - "how doe the fitbit know how much you've walked" - takes on an increasingly terse tone and as Joan's suffering intensifies the screenplay contains one particuarly bitter exchange. It takes place during the chemotheraphy phase of treatment and when Joan asks Tom for painkillers. Ever fastidious, he reprimands her for not writing down the correct order for taking them but this quickly escalates. Impatient with his chastisements Joan accuses him of trying to co-option her predicament: "Whose pain is this - mine or yours ... This isn't about you". "We're both 
going through this", he replies. "No Tom, no we're not - I am - I'm going through cancer, I'm going through chemo..." .

The argument represents a rare moment of anger and disharmony in their relationship, although they bicker on other occasions and for similar reasons - when Joan feels Tom is overstepping her status as the patient. (She asks him not to so forcefully intervene in discussions with her onchologist - "Its embarrassing"). The eruption does however offer a glimpse of another dimension of longtime companionship - the submersion of the individual as well as the emotional labour and stress of spousal care-giving amongst ageing couples. This latter aspect is particuarly underappreciated and underrepresented in our society but - as the mere existence of a film like Ordinary Love suggests - likely to come more to the fore in the years ahead as western populations age rapidly.

And it is in this respect - the theme of aging - that the film, which remains a hermetic and specific narrative on so many levels and apparently working outside of recogizable genre conventions, might be found to intersect with wider trends and concerns. It is notable for instance that along with its moderist aesthetics the filmmakers erase - or at least minimize geographical landmarks or social context for the story which, notwithstanding a large number of Northern Irish accents, focalizes the couple and their private struggle. While this might be considered illustrative of a post-ceasefire dispensation in Northern Irish cinema (a permission to move beyond politics), the film nonetheless connects with the growing visibility of ageing in contemporary popular culture in general and the ageing couple in particular.

It might for instance be compared to recent texts such as 45 Years, Le Weekend and Bernard MacLaverty's 2017 novel Midwinter Break (currently being adapted for the screen) or the more gruelling Iris and Amour. While all centre on ageing couples, the latter two, like Ordinary Love foregrounding illness and the theme of spousal care and, curiously it is notable that it is men that fulfil the primary care role in all three]. Ordinary Love is distinctive in foregrounding a "younger" couple than the others, although not long ago Neeson and Manville, aged 67 and 64 respectively, might have been considered "old". But it shares with these texts a contemporary interest in ageing in contemporary European film which frames its subject in terms of the white, middle-class couple, relatively insulated from social shocks or striving, and turned inwards. The couples in these stories are post-employment yet relatively prosperous, their roles as workers or care-giving parents are past, their social circles diminished or even disappeared and their days are filled with essentially leisure-time and activities of consumption such as shopping, travel or coffee shops [the supermarket is the third location in Ordinary Love]. Additionally, such characters are frequently played by respected "elder" stage/screen actors and as such bring associations of both culture and "national" values, lending otherwise enclosed narratives broader social resonance.

While Haneke's Amour is the most extreme instance of this recent narrative, confronting a harrowing end of life scenario, it nonetheless shares similarities with Ordinary Love including themes of declining body and spousal care. It is also notable that both films (as well as Iris) frame these themes in gendered terms with care coming from the male while it is the female who physically suffers: this is the direction and meaning of love in both titles. The casting of Neeson in this role is not insignificant: he virtually invented the "geri-action" genre with the Taken films. ${ }^{2}$ While Ordinary Love returns Neeson to home territory (in terms of its setting and location), and his character is insistently attentive and loving, he maintains a physical completeness and manliness in the role that quietly but unequivocally maintains gender norms.

If Ordinary Love offers a more optimistic treatment of ageing than Amour, it is partly because it imagines these issues in relation to a younger couple but primarily because it takes a far more hopeful view of the health service on which its central characters depend. While health professionals in the film remain realistic in their diagnosis ("nothing is normal") they 
remain conspicuously peripheral, the camera usually preferring to remain focused on the central characters. Tom and Joan - and the film's POV - faithfully submit themselves to a system that is accessible, sophisticated and ultimately successful. Compare this to say the experience of characters in The Life and Death of Mr Lazarescu (2005) or even Amour and the film emerges as much a celebration of the extraordinary and endangered NHS as it is of the "ordinary love" between a couple who, back in the supermarket (their status as both healthy consumers reasserted) are last seen gently squabbling about how many Brussels sprouts to buy.

\section{Notes}

1 "Producer Brian Falconer discusses Ordinary Love with IFTN". 1 March 2020. http://www.iftn.ie/news/featureinterviews/?act1=record\&only=1\&aid=73\&rid=4293124\&tpl=archnews\&force= 1

${ }^{2}$ Donnar, Glen. "Narratives of Cultural and Professional Redundancy: Ageing Action Stardom and the 'geriaction’ Film”. Communication, Politics \& Culture 49 (2016): 1-18.

Tony Tracy lectures in film and digital media at NUI Galway. He is co-author (with Roddy Flynn) of the Historical Dictionary of Irish Cinema, $2^{\text {nd }}$ Ed. (Rowan and Littlefield, 2019).

tony.tracy@nuigalway.ie

\section{Postcard from the edge Losing Alaska (Tom Burke, 2018)}

\section{David Robbins}

For about 30 years now, scientists, academics, journalists, filmmakers, NGOs and others have been trying to answer a deceptively simple question: how to get the public engaged with the topic of climate change. More particularly, they have wondered about visual communications - what imagery works with audiences?

The polar bear standing on floating ice, smokestacks in the distance, wind turbines on a mountainside - all these visual tropes have been tried, and all have drawbacks. Indeed, they are so hackneyed now as to become almost meaningless. A focus on the impacts of climate change, such as the loss of habitat for polar bears, frames climate change as a looming catastrophe, and can shock audiences into attention, but can also induce a sense of fatalism.

Al Gore, in his documentaries An Inconvenient Truth (2006) and An Inconvenient Sequel: Truth to Power (2017) foregrounded the catastrophe frame, with footage of rain storms, floods, droughts and wildfires. "WATCH the water splash off the city", cries Gore in the second film, almost revelling in the destructive power unleashed by climate change. It is verging on climate porn: gorgeous, curated imagery that seems somehow distant from us. The scale is too vast, the systems too global. A smaller canvas is called for.

Some filmmakers have narrowed the focus from global governance and planet-wide weather systems towards people and communities. For example, Thule Tuvalu (2014) looked at two communities distant from each other: Thule in northern Greenland, and Tuvalu, a Polynesian island. In each case, a way of life is under threat from climate change, but there is 
an extra twist. The ice melting from Greenland is drowning low-lying Tuvalu, thousands of miles to the south. Emphasising the new smaller scale focus, one reviewer praised Thule Tuvalu as "...one of the earliest [films] to sideline impersonal statistics and talking-head scientists, focusing instead on the communities directly affected" (Weissberg).

There has been a significant shift away from a global perspective on policy and climate impacts (as in the Al Gore documentaries) and towards a focus on solutions and a human scale perspective. Demain/Tomorrow (2014), a French documentary focusing on climate solutions, is an example. The ground-level perspective is also evident in recent documentaries such as After The Fire (2019), Last Call for the Bayou (2019) and Lowland Kids (2019). The news media have stopped treating climate change as a single, homogenous topic and have begun to report on constituent issues such as pollution, air quality, fracking and agricultural systems. The same is true of the visual media, with films such as Gasland (2010) (fracking), Mossville (2019) (petrochemical pollution) and The Story of Plastic (2019) (plastic production) dealing with issues that contribute to or are caused by climate change, rather than with the over-arching problem itself.

Into this increasingly crowded and evolving field comes Losing Alaska by Irish filmmaker Tom Burke, a beautiful, often moving observational documentary about the people of Newtok in Alaska, whose village is at risk from the melting permafrost and coastal erosion. Although the film is book-ended by footage of a 2015 speech by President Obama in which he warns about the impacts of climate change on Alaska, harking back to a time when the notion that climate change is a hoax perpetrated by the Chinese to weaken the US economy had yet to take hold. There is otherwise no mention of climate change in the piece. The locals - mostly native Youpik people, plus a few white Americans - do not talk about the climate. They talk about "the river" and its increasing proximity.

The film opens with series of shots of locals looking up as a light aircraft comes in to land. Aerial shots show houses and boardwalk-style roads, clumps of melting snow and a soggy landscape, with grass the faded yellow it gets when it's been covered by snow for a time. A framed photo shows coastal erosion over the past years. The sea has just claimed 30 feet of land over a stormy few days. The land looks soft and peaty, and the waves hit it hard, burrowing under and leaving precarious platforms overhanging the waves. "The land falls down and cannot pick itself up", says Bosco Charles.

Another interview subject, Jackie, puts the village's plight in historical context. The federal government would build a school and a post-office and force the Yupic people to settle around these symbols of "civilisation". Their nomadic lifestyle came under threat, especially when the government began to take their children and put them in boarding schools. "When you have been doing something for 15,000 years, and someone puts a stop on it, the consequence is what you have now", she says.

What do you have now? A village living at the edge of the world, between land and sea and between the future and the past. There are two rival village councils, one more modern and forward-looking, the other more traditional and elder-led. "We're part of the US the rest forgot", says one. The new council was elected at a meeting of locals, but the old one refused to stand down. There are two native administrators - Tom John (new) and Stanley Tom (old) - with the result that the Federal Government doesn't know which to deal with.

The Youpics are subsistence hunters. They catch and kill $95 \%$ of what they need. "They would survive if they couldn't get to a store", says one of the white American women. They hunt for seal, using binoculars and rifles in place of the harpoons of old. Burke includes some beautiful footage of a calm day at sea, the sun shining on the glass-like surface, until the crack of a rifle breaks the spell. The hunters motor up to their prey, dispatching the seal with a kill shot. They dry the flesh in the wind. 
The white Americans in Newtok offer an outsider's perspective. Kevin, a teacher at the school, and his family were welcomed by the Youpic and feel part of the Youpic family. His wife sits with the other white women, playing cards and talking about how Newtok has been forgotten by the rest of America. "There is no running water. They've been on a boil water notice for 10 years", says one. "You don't expect this in America", says another, referring to the shacks and timber houses that make up the village.

The Youpic seem like calm, thoughtful people, slow to anger and quick to laugh. The white Americans speak of the welcome they received from the Youpics, of the sense of family that abounds in the settlement. The schoolteacher Kevin tears up when he thinks about it. Burke records some beautiful images of village life: groups of kids playing basketball outside, their movements silhouetted against the sky, their breath suspended in the freezing air. And some surreal images, as the kids go trick-or-treating at Halloween and Malificent, some vampires and dinosaurs whizz by on quad bikes. Or a group of women sitting outside, gutting fish as the wind howls. He captures well the gossipy closeness of small communities. The talk is of those who are moving, those thinking of moving, and those who have moved. And of the sea and its encroachment: "It's getting awfully close to Nathan's house".

One family have moved to Anchorage, and the contrast is stark: traffic and streets in place of quiet and vast skies. The movers still talk of Newtok, and use the same, all-purpose cutting tool - like a small axe-head - that the Youpic use back in the village. At least they have plumbing. Back in Newtok, they use the wonderful euphemism of "honey buckets" for the five-gallon drums of human excrement they throw into the sea.

Others are planning to move to a new village supposedly being constructed for them in Mertarvik, across the bay. Mertarvik is safer, more sheltered and built on higher ground. There is footage of the US Marine Corps helping to built it a few years previously, but the plan seems to have run out of steam, or money. Now it is back on the agenda, and the issues of who is leaving and who is staying is a constant topic in the village.

What draws an Irish filmmaker to this story? Landscape, for one. The beautiful aerial shots of Newtok, which sits between where the Ninglik and Newtok Rivers enter the Bering Sea, reveal a place that looks like the west of Ireland: a boggy, watery expanse, pockmarked by small lakes, a land that is half water already. And community, for another. This tale of a remote group neglected by officialdom and the elites of the "lower 48 " has resonances with the Irish experience.

The film addresses universal themes too: the pull and tension between tradition and the old ways versus modernity and the need for change. This tension is too much for some: suicide is a dark undercurrent in Newtok, and online bullying takes place even at the edge of the world.

The film ends with that circling plane. We know now that it is coming for the schoolteacher Kevin and his family. In the time the viewer has spent with the people of Newtok, the phrase climate change has not been uttered, yet the impact of the warming climate and the melting permafrost have been powerfully conveyed. Perhaps the best way to deal with climate change in a documentary is not to mention it at all.

\section{Works Cited}

Weissberg, Jay. "Film Review: Thule Tuvalu". Variety. 11 September 2014. https://variety.com/2014/film/festivals/film-review-thuletuvalu-1201307101/ 
Dave Robbins is Assistant Professor at the School of Communications, Dublin City University. His research centres around media representations of climate change, journalism practice as it relates to the coverage of environmental matters and media framing effects. His $\mathrm{PhD}$ (2018) research also concerned the topic of print media coverage of climate change in Ireland from 2007 to 2016 and has been subsequently published as a book by Routledge.

david.robbins@dcu.ie

The Hole in the Ground (Lee Cronin, 2019)

\section{Denis Murphy}

Director Lee Cronin's feature debut, The Hole in the Ground, had the most prominent release of any domestic Irish film last year. Backed by a strong marketing campaign, the film was distributed to 70 screens around the country and became the best-performing indigenous film of 2019 (Bramhill 2020). This article locates the film within the wider cycle of Irish horror output, a corpus linked by Barton (2019) to Roger Corman's low-budget Connemara studio operation, co-created with Udarás na Gaeltachta in 1995. As the film would not exist without public funding, and because such funding is often justified in terms of economic (particularly employment) benefits, I investigate its production history in terms of the career development of its makers, including their wider network of industry contacts and creative workers. The focus on these industrial and labour aspects of The Hole in the Ground's development, production and exploitation is undertaken with a view to exploring the "intellective and physical labour" at the heart of media production and dissemination, addressing what Vincent Mosco terms the "labour blind spot" in western film, media and communication studies (Mosco 2011: 358).

In the film, Seána Kerslake plays Sarah, a young mother who moves with her son Chris (James Quinn Markey) to a semi-rural village, in the aftermath of an apparently toxic relationship with the child's father. When Chris begins to act strangely, Sarah links his disturbing personality changes to the mysterious crater she discovers in the nearby woods, eventually concluding that the boy is not, in fact, her son. Cronin and co-writer Stephen Shields thus draw on Irish "changeling" folklore: the child kidnapped by a supernatural presence, replaced with an imposter. True to generic convention, no one but Sarah seems concerned about Chris, except their eccentric neighbour Noreen (Kati Outinen), the "wise old woman" whose function is to identify the imposter and restore normality by setting in motion a gruesome chain of events (see Mac Philib 1991).

Of Corman's Irish-made films, Barton identifies two in particular - House of the Damned (1996) and Wolfhound (2002) - that draw on "Irish gothic" elements (shadowy castles, haunted cellars, domestic terror), paving the way for subsequent indigenous films like Isolation (2005), Boy Eats Girl (2005) and Wake Wood (2010) to present the Irish countryside as a "credible site for horror" (Barton 70). The Hole in the Ground undeniably contributes to this emerging tradition, mobilising a range of generic tropes to fashion a chilling "bog gothic" atmosphere. Cinematographer Tom Comerford depicts a washed-out, brooding natural landscape of unmanicured meadows and eerie woodland, where the beckoning crater and its 
ghoulish inhabitants imbue the liminal village location with "fear and anxiety... the sublime and the supernatural" (Gladwin, quoted in Barton 70). Sarah's progression through suspicion, conviction and ultimate decisive action is an ambiguous journey through madness or heroism, depending on the spectator's interpretation of unfolding events. The woodlands and their concealed horrors threaten Sarah and Chris's existence, placing the film firmly in the "revenge of nature" cycle through which some Irish horror films have articulated contemporary environmental anxiety (Barton 70). Perhaps crucially, this vengeful landscape is not particularly identifiable as Irish, while the eclectic casting of Irish, Finnish and Scottish actors further enhances its borderless appeal.

As a feature debut, The Hole in the Ground marks a career milestone and an opportunity to appraise the developing career arcs of its makers. Cronin, who hails from the north county Dublin village of Skerries, emerged in 2004 when his IADT student comedy Wilbur \& Anto won Best Film at the Cinemagic Young Filmmaker competition in Belfast. Six years later, Cronin formed Rank Outsider Productions with producer John Keville and made Through the Night (2010), an atmospheric horror short. This project drew together for the first time a creative nucleus that has remained intact ever since: Cronin, Keville, Comerford, and editor Colin Campbell. Soon afterwards, Rank Outsider increased its momentum with Billy and Chuck (2011), with funding from the long-running Filmbase/RTE Shorts scheme. The Masterplan (2011), an episodic drama produced for the RTE Storyland competition, followed.

The Filmbase scheme (discontinued with the organisation's demise in early 2018) had been unearthing future Irish feature directors for almost 30 years. Rank Outsiders' participation thus boded particularly well for its founders' careers, borne out when the team's next project, the stylish horror short Ghost Train (2013), premiered at Clermont-Ferrand, the most significant "A-List" festival on the European short film circuit. The film's development had seen Cronin and Keville leverage their growing reputation in the short format, securing a slot at Euro Connection 2012, an annual networking event matching filmmakers with international funders. Pitching the Ghost Train script, the duo secured $€ 35,000$ from the Finnish Film Foundation, a commitment that encouraged Keville to approach the Irish Film Board (IFB) for additional funding. While the amount of the IFB contribution is unclear, it seems likely that the Board contributed the remainder of the film's total budget, listed as $€ 101,000$ by the Finnish Film Foundation (SES Ghost).

Ghost Train proved an effective calling card. Its festival success and the reputational afterglow enjoyed by the contributing screen agencies enhanced Rank Outsider's status with the public funding bodies. When the film won Best Short at San Sebastian in October 2014, Cronin had already received a development loan for The Hole in the Ground (IFB 2015, 27). The script attracted more funds in 2016 (IFB 2017, 31), bringing total IFB development support above $€ 40,000$, a relatively large amount reflecting the Board's considerable confidence in the project. To make the film, Rank Outsider combined forces with Savage Productions, a Dublin company with a track record in features. Shooting commenced in 2018 on a budget of about $€ 2$ million, about two thirds of it from Irish sources (Table 1).

Table 1: Estimated budget sources

\begin{tabular}{|l|l|}
\hline Source & Amount \\
\hline Screen Ireland & 650,000 \\
\hline BAI & 125,000 \\
\hline Section 481 (est.) & 510,000 \\
\hline Finnish Film Foundation & 100,000 \\
\hline $\begin{array}{l}\text { Other sources (Wallimage, A24, Head } \\
\text { Gear, Bankside, RTE, etc.) (est.) }\end{array}$ & 615,000 \\
\hline
\end{tabular}


\begin{tabular}{|l|l|}
\hline Total & $2,000,000$ \\
\hline
\end{tabular}

To complete the budget, the filmmakers built on their Ghost Train network to configure the film as an international coproduction. Demonstrating the value of EU-level industry contacts developed under initiatives like Euro Connect and EAVE (an EU-funded producer's network), Keville reunited with Ulla Simonen, the Finnish co-producer on Ghost Train, triggering another $€ 100,000$ contribution from the Finnish Film Foundation (SES Hole). Belgian co-production status was achieved through a relationship with Benoit Roland, who had co-produced the 2015 feature You're Ugly Too with Savage. Wallimages, a regional Belgian film fund, added further diversity to the funding mix. With all of these publicly funded commitments in place, the remainder of the $€ 2 \mathrm{~m}$ budget was raised through deals with international distributors and financiers, and a 24-day shoot ensued in Dublin, Wicklow and Kildare. The co-production status necessitated some quid-pro-quos, with several Belgian and Finnish companies contributing to the film's sound, special effects and post-production elements, and the casting of Finnish actors in two prominent roles.

By the time of the film's prestigious premiere at the Sundance festival, The Hole in the Ground was a hot property by Irish standards. US theatrical rights were in the hands of A24, an indie distribution specialist whose success in marketing low-budget horror films like The Witch (2016) and Hereditary (2018) suggested similar ambitions for the Irish film. Deals with Vertigo Films and Wildcard Distribution underpinned a planned wide release in the UK \& Ireland. Further sales would bring the film to theatres across Europe, South America, Asia and Australia.

But as William Goldman memorably insisted, in the film business "Nobody knows anything", and the thinking behind the film's initial release schedule, in Ireland and the US at least, proved wishful. Its Irish chart-topping status did little to disguise a disappointing take of $€ 141,000$. Off similarly wide release schedules, 2018's Black '47 (€1.5m) and 2017's Cardboard Gangsters ( $€ 182,000)$ had proved considerably more popular with Irish audiences, suggesting that these two films had capitalised more successfully on their respective western and urban gangster genre appeal. At the box office at least, The Hole in the Ground failed to achieve similar penetration with Irish horror fans. A meagre take of $\$ 21,000$ suggested that US audiences were similarly nonplussed.

In non-anglophone markets, however, the film proved far more resilient. According to Box Office Mojo, it amassed a respectable $\$ 3.37 \mathrm{~m}$ worldwide, mostly in Mexico, Italy, Germany, Russia and the UAE. Following this initial release, the film was sold to the Netflix and Amazon Prime streaming services, where it continues to be available to a wide audience.

The production history of The Hole in the Ground effectively illustrates the value of incremental advances, long-term relationships, and a successful negotiation of the international funding ecology in building creative careers, answering Mosco's call to better understand "the work that goes into communication and culture, and the workers who perform it" (362). Ultimately, The Hole in the Ground found a global audience, a success enabled by its skilful application of horror conventions; a committed cast; a well-functioning creative and producing team with experience amassed over time; and a history, perhaps crucially, of working with children and young actors, a recurring feature of Cronin's oeuvre.

\section{Works Cited}

Barton, Ruth. Irish Cinema in the Twenty-First Century. Manchester: University Press, 2019. 
Bramhill, N. "Ireland's Love of Big Screen Continues as Box Office Enjoys Best Year in Decade". The Examiner. 7 January 2020. 5 March 2020. https://www.irishexaminer.com/breakingnews/entertainment/irelands-love-of-bigscreen-continues-as-box-office-enjoys-best-year-in-decade-974065.html

IFB. Annual report 2014. Galway: Irish Film Board, 2015.

IFB. Annual report 2016. Galway: Irish Film Board, 2017.

SES / Finnish Film Foundation (2020). Ghost Train. 3 March 2020. https://ses.fi/en/elokuva/ghost-train/

SES / Finnish Film Foundation (2020). Hole in the Ground. 3 March 2020. https://ses.fi/en/elokuva/hole-in-the-ground/

Mac Philib, S. "The Changeling: Irish Versions of a Migratory Legend in their International Context". Béaloideas, 59 (1991): 121-131. 27 February 2020. https://www.jstor.org/stable/20522381.

Mosco, Vincent. "The Political Economy of Labor". The Handbook of Political Economy of Communications. Eds. J. Wasko, G. Murdock and H. Sousa. Chichester, Sussex and Malden, MA: Wiley-Blackwell, 2011. 358-380.

Denis Murphy is Research Fellow in Film Studies at TCD, working on the Ecologies of Cultural Production project funded by Creative Ireland. He is a graduate of Dublin City University (BA Communications, MA Film and Television Studies), and also holds a doctorate from DCU for research on the labour history of film and television drama production in Ireland. $\mathrm{He}$ is a regular contributor to Estudios Irlandeses among other publications.

denis.murphy@tcd.ie

Dark Lies the Island (Ian Fitzgibbon, 2019)

\section{Siobhán Kane}

We begin with a young woman staring into a busy body of water, the local lake, staring as if searching for an answer, the kind of staring that could get you killed in this part of the country. The lake, our narrator tells us, gives off "a wicked aul' draw", a draw that "turned half the place crooked in the head".

Adapted by Kevin Barry from his own stories, and directed by Ian Fitzgibbon, Dark Lies the Island brings into play the Mannion family who have run Dromord ("this godless hole of a place") for generations. The family, presided over by the brutal, dominant "Daddy" Mannion, (expertly inhabited by Pat Shortt) and sons, own everything.

The agoraphobic son Doggy (Peter Coonan) now lives in a caravan in the woods, where he runs illegal businesses, on several different phones, mirroring and exploring a kind of moral relativism-are the legal businesses the rest of his family run (pub, undertakers, estate agents) any better because they are in the light? Don't both "serve" the community?

The feckless second son Martin (Moe Dunford) disappoints Daddy at every turn, with hare-brained schemes and failed enterprises. All orbit the moon that is the disappointed, tormented Sarah (Charlie Murphy), previous partner of Doggy (her "true love"), lover of 
Martin, but married to Daddy, with a daughter (wonderful newcomer Jana Moheiden), she becomes a potent axis in a vortex of lacerated wounds, barely concealed bitterness and taut compromises.

In the midst of such tautness, Richie (a brilliantly doleful Tommy Tiernan) arrives, seeking something more, but finds himself running the local chip shop; it quickly becomes clear that Dromord is a place that can drown the dreams right out of you, give you the "green bloat". Richie's arrival brings with it a kind of altering alchemy, changing the paths of the dysfunctional Mannions forever.

Barry's tales of Irish small-town rurality, banality, and immorality have always contained an epic quality, a swaggering, reckless grace that transferral to the big screen rewards. The film suggests a Sergio Leone-Coen Brothers-Harold Pinter hybrid, a different kind of western, harnessing the Irish obsession with the "outlaw" and outliers, the wonkiness to be found in community, from the innocently eccentric, to the dangerously maniacal, and the power that language can hold when weaponised, to control and diffuse any given situation.

This is where the potency lies in the film-language; all different kinds. Cathal Watters' cinematography speaks to Barry's carefully drawn characters - "20 years dying" in all different ways, all deft close-ups, illustrating claustrophobic lives, painted into epic landscapes, making the tragedies all the more pronounced, and Stephen Rennicks' (Room, Frank) score walks a line of playful darkness, the elegant against the grotesque that flits around the unfolding associative dramas like a warning sign.

In Dromord everyone lives amid thwarted hopes and chaotic existences; smaller characters' lives underscore the malaise that rips through the town like a farmhouse fireDoggy's acquaintances Patcho (Eoin Geoghegan) and Tee-Jay (Charlie Kelly) who are tasked with spying, are presented as slapstick stooges, and Daddy's colleague Phyllis (the great Aisling O'Sullivan) suggests a loneliness, which is amplified when she sings Amazing Grace in the woefully out-of-place karaoke bar. But everyone and everything seems to be out-ofplace, and out-of-joint, and yet so perfectly where they should be.

This theme of accepting the unacceptable until it becomes the norm weaves its way into this story of shattered lives looking for a reckoning with something, someone, anything. And the final reckoning is paced well, the tense interactions that Daddy has with his sons, that they have with each other, that Sarah has with them all, brings to mind Pinter's play The Homecoming, and its exploration of sex and power, and language as power. It is a work of resentment, where menace replaces ethics in its underpinning.

Another influence is McGahern, whose ghostly hand hovers within the subtle savagery. Doggy's consoling of a client of his dating service "I've a folder here, full of fellas who's tongues would be hanging out of their heads for a 22 dress size" borrows from McGahern's The Leavetaking, the lake's image and potency from That They May Face the Rising Sun, and thematically, that sense of place that McGahern's writes so well, and its attendant fractiousness, the dysfunction that is barely navigated, and the power of resilience to make it through, perhaps not life in totality, but another day, at least.

In Dark Lies the Island, time is presented as a discombobulating thing, we see people come to the end of their lives naturally, and unnaturally, we see the living dead, walking their way through the day, medicating any which they can. There is a suggestion that it has always been this way, in Dromord's all around the place. We could be in 1870, 1970, or now-but small details situate us in a more modern moment, the visit of the Organic Certification Board to Martin's chicken farm, for example, although Doggy's retro dating service is all folders and phonecalls. 
This is another part of the film's charm; the duality, and subversion that takes place in almost every scene to deliver a real sense of this twisted community, where the extraordinary and the everyday are placed alongside each other so repetitively, that it begins to carry its own rhythm.

"What kind of child can't get herself addicted to the fucking internet?" Sarah says, as she fails in encouraging her daughter to get distracted by the tablet. Barry interrogates what we have allowed to become the norm, across an entire spectrum, marrying our transgressive, disconnected relationship to the internet, for example, with the transgressive disconnected relationships within the Mannion family-it's both clever and persuasive.

There is a disconcerting, yet attractive energy to Fitzgibbon's pacing of the film. It is clear that these scenes are essentially a series of vignettes, but they are stitched together in such an interesting way that it works, perhaps because there is a philosophical realism at work-an acknowledgment that life itself is a series of vignettes. But in Dark Lies the Island, the normal "rules" of living are observed and subverted to the point where we begin to wonder if we are indeed, as Sarah muses, "only the reflection ... what if the real town is down there in the black water?"

Sarah's daughter becomes a kind of totemic presence, a voice of reason, often conveying a logical take on the depravity, which is depravity in itself, but her world-weary wisdom, and spark of potential, suggests that perhaps a second-act is coming, to borrow once more from McGahern and his 1979 novel The Pornographer "Yoo-hoo, Road! Yoo-hoo, Road!". For some, this will mean getting out of Dromord, an act of severing, for others it will mean an act of staying, of stepping into dead men's shoes and repeating the cycle. "Yoo-hoo, Road! Yoo-hoo, Road!”

Siobhán Kane is lecturer at University College Dublin where her present research project is on John McGahern. She has an interest in interdisciplinary studies, and also works as a music and arts journalist, and broadcaster, for The Irish Times, WIRE, The Quietus and RTÉ. She also runs the arts collective Young Hearts Run Free, putting events on in unusual spaces and raising money for the Simon Community.

siobhankane@gmail.com

\section{The Curious Works of Roger Doyle (Brian Lally, 2018)}

\section{Stephanie McBride}

"The Godfather of Irish Electronica" is the label most frequently used to classify Irish artist Roger Doyle and his work. This meme persists in media mentions and profiles about Doyle, from listings and features on RTÉ's website (where the phrase occurs at least four dozen times) to The Irish Times ("about 136 results" according to Google). While the label is an expression of respect, and while Doyle is indeed among the leading exponents and earliest pioneers of electronic music in Ireland - for example, he was one of the first people in the country to work on a Fairlight synthesizer / digital audio workstation - it hardly does justice 
to his wide-ranging career as a composer, musician and performer, as well as a body of work that refuses to be pinned down in any one genre. For more than half a century now, Doyle has had an almost Zelig-like presence in the Irish avant-garde, appearing in so many times and places - from gigs by early prog rock bands to the music credits on films by the likes of Bob Quinn and Joe Comerford, to acclaimed experiments in dance and theatre. As a longstanding member of Aosdána, Ireland's state-sponsored academy of creative artists, Doyle's preeminence in the arts was further recognised in 2019 when he was conferred as a "Saoi" (wise one).

Biographies can be difficult to structure at the best of times, and even more so for an artist with such an extensive CV. Brian Lally's The Curious Music of Roger Doyle (2018), a feature-length documentary about Doyle's life and music, uses his first opera Heresy as a narrative anchor around which to build a relatively fluid overall structure. The rehearsals for the opera's premiere at Project Dublin in November 2016 are punctuated by flashbacks to Doyle's previous works and performances, as well as interviews and musings, as well as clips with some of his many artistic collaborators.

Before analyzing Lally's film in more detail, it is worth sketching just some of the many milestones in Doyle's career. In the early 1970s he studied composition at the Royal Irish Academy of Music and at institutes in the Netherlands and Finland; he was also a drummer with various experimental bands including Supply, Demand and Curve, a jazz-rock group whose strange music alerted many music students, steeped as they were then in piano etudes and two- and three-part inventions, to other sonic possibilities. His debut album Oizzo No (1975), an electro-acoustic mixture of works, became cult listening. Meanwhile he began composing scores for what would turn out to be a Who's Who of experimental Irish filmmakers, from Joe Comerford's shorts Swan Alley (1969) and Emptigon (1971) to Cathal Black's Pigs (1984) and Bob Quinn's Budawanny (1987) and his Atlantean series (1984). In 1981 Doyle co-founded the music-theatre-dance company Operating Theatre with actor Olwen Fouéré, and the duo produced many acclaimed site-specific productions. He also wrote and performed the music onstage for Steven Berkoff's "slow-motion" version of Oscar Wilde's play Salome at Dublin's Gate Theatre in 1988, and later at its West End run in London and on three world tours.

Around 1990, Doyle began work on Babel, an evolving series of pieces that celebrate the multiplicity of musical languages and evolving technologies; each track would correspond to one of the many interlocking rooms or zones within a giant tower-city. He developed another large-scale series of electronic works, Passades, over 2002-07. In 2013 he founded Meta Productions with opera director Eric Fraad, to explore new forms of opera including Doyle's full-length work Heresy.

For the greater part of its duration, Brian Lally's documentary about Doyle adopts a fly-on-the-wall approach. Its opening eavesdrops on the composer in a masterclass at the Science Gallery in Trinity College Dublin, as he performs on a reconstructed Moog synthesizer. The instrument, he tells the students, predated him as it was a product of the Sixties and his own musical beginnings were in the Seventies. This date leads neatly into a series of photographs of a younger Roger in performances before bringing us up to date as he sits in his home, packing CDs to send off at the local Post Office. He talks of the pleasure it gives him - "sad but glorious" and, in answer to an unheard question, he explains that this probably yields the cost of cappuccino a day - "Not bad for a composer of contemporary music," he jokes.

The director, having clearly built up a rapport with his subject, allows viewers into Doyle's reflections as he recounts his development as a composer. On screen he recalls wondering what to do after leaving school - a time when he was playing drums, poker and 
smoking - before gaining a place at the RIAM based on his early compositions. This was followed by a time at the wonderfully-named Institute of Sonology in Utrecht, where he was required to master a complex studio system. Before being let loose to play, students had to complete 22 studio exercises to know the destination of each cable. At this time too, he was earning recognition as an important emerging contemporary composer.

Despite the documentary's focus on one artist, it also draws us into a rich cultural history of alternative and avant-garde art in Ireland during the 1970s and 1980s, a vigorous if underfunded period of cultural production in the country. Doyle's reminiscences of his teenage gang - which included an actress, painter/filmmaker, poet and a sculptor - are both humorous and insightful. A clear gem in the documentary is the number of interviews with artists he has collaborated with, such as Cathal Black and Joe Comerford (a fellow gang member) and, a little later, Olwen Fouéré. Doyle went on to compose soundtracks for many of the new wave of Irish films in the 1980s, and Black explains how Doyle's music added further narrative and emotional layers to the ending of his film Pigs. Each young artist was intent on developing his own language - for Doyle a language of sound, for Comerford and Black a language of film. The Sheridan brothers' Project Arts Centre was another hub of progressive artistic ferment, especially in theatre. The Project was a significant venue in Doyle's early career, so it seems a fitting venue for his first opera, Heresy.

Long-time collaborator Olwen Fouéré describes how she and Doyle had a taut, demanding yet always rewarding working relationship, as both were determined to stretch the contours of their practice. In particular she explains the exacting physical demands performing Doyle's Passades, extending the range of the possible in movement and performance. Through Fouéré we get a strong sense of the unflinching commitment necessary in pushing the boundaries of art forms.

More insights come from film-maker Bob Quinn; he recounts making a film based on Doyle, Listen (1978), as a response to an RTÉ-commissioned theme on alternative lifestyles. Quinn, ever the maverick, jettisoned any conventional notions of "alternatives" such as doing something about cheese makers, and argued instead for a film concentrating on Doyle's sound art: the rhythms of a boiling kettle dissolving into the rattle of a moving train, and so on. Quinn, who affectionately refers to Doyle's work as "squeaky gate music", was also wittily precise in his requests to the composer for film music, telling Doyle that he needed "around two inches more, or maybe a foot more", for a particular film sequence.

The documentary showcases Doyle's openness to different forms of sound. The tracks of his 2011 album Time Machine are built largely on a reworking of old voice messages left on his answering machine. A set piece in the documentary features the voice of the late Jonathan Philbin Bowman, as Doyle transforms the journalist's midnight stream-ofconsciousness answerphone message into Coat Hanger Kisses in a collage of voice, piano and text. In a highly charged moment in the film, Doyle also plays the voices of his own parents in recordings of their telephone messages - powerfully intimate, poignant reflections, trembling through time and memory, with a plaintive "And look after yourself" signing-off from his mother. Family photo albums have a strong emotional pull, but here it is the grain of the voice that preserves a unique sonic memory, in a family album of voices.

With Arts Council funding in 2015, Doyle's opera Heresy was developed as a major feature in the 50th anniversary of Dublin's Project. The opera's director, Eric Fraad, revels in the undertaking because it is "unlike any other opera seen in Dublin ... outrageous, provocative", which also characterises the opera's subject, the brilliant and controversial Renaissance figure Giordano Bruno. Burned at the stake in 1600 after a nine-year trial by the Church's Roman Inquisition, Bruno had envisioned an infinite universe without a centre, and the possibility that other galaxies might foster life of their own (a philosophical position 
known as cosmic pluralism). Lally's fly-on-the-wall filming of the rehearsals offers glimpses into the skill and technique of the singers, testing and exercising, revealing the demands on the voice for the stretch of a long note. There is also interaction, interpretation, and direction as Doyle taps out the rhythm, gradually building up the tempo. At other times, the glorious rarefied operatic sounds come to an edit by the call for a tea break.

After the insights of rehearsals, after all the notes and amendments, comes the big reveal in the film's narrative climax - the opera in performance. Using a combination of close-ups, reaction and master shots from carefully selected sections, the documentary presents the magnificently sparse stage set, an uncluttered symmetry of geometric shapes, a backdrop for changing colour tones - gold, silver, coral, midnight blue. In this setting for the soaring, searing purity of voice, words and phrases emerge - "transubstantiation", "the earth revolves around the sun" - recalling the contested legacies, ways of seeing and of the seismic force of Bruno's science. Lally's chosen segments skillfully condense the opera for audiences both as a sonic and visual pleasure.

Yet notwithstanding Doyle's contribution to Ireland's cultural landscape over five decades, and in spite of his prolific output throughout that time, a central theme of the documentary is how this internationally acclaimed composer is relatively neglected in his own land. Or, as musicologist Barbara Jillian Dignam puts it in the Journal of Music, the film's underlying question is "why does Roger Doyle's music still go largely unnoticed by the Irish public?" Dignam concludes that there's no easy answer. Historical relations between contemporary music, funding bodies, organisations and Irish audiences - not to mention formal music education with its prescriptive canon doing little for the dissemination of experimental works, let alone those by Irish artists - require consideration. Lally does not partake in such intense debate.

Although the documentary's structure achieves narrative coherence, flow and climax, by its very nature it is a partial account. Babel, composed and revised over a decade and stretching to five albums, is curiously absent from the film. The project, which the Contemporary Music Centre calls "his magnum opus" and is described in the "Biography" section of his own website as "his life's work", was released as a mammoth five-CD set in 1999. An earlier version of Babel was also released as the first free CD with an Irish art magazine, as part of the "work in process" series in Circa Art Magazine in 1994.

In an otherwise elegantly visualised documentary, the film's title typeface - a form of data compression itself - seems clunky. Another weakness is a sequence featuring Doyle performing Chalant in the ornate surroundings of Centre Cultural Irlandais in Paris. Instead of offering the concert extract per se, the sequence is punctuated by arbitrary cutaways to unknown and unidentified persons around Paris, and this jolts as visual clutter instead of being sympathetic to and directly serving the performance; a quote from Thomas Jefferson in no way cushions this incongruous, intrusive wallpaper. It is as though the camera is afraid to stay with the performer, because the audience needs a constant feeding of visual "extras". The treatment here contrasts sharply with a sequence after the opera premiere, in which Doyle's wish to perform Adolf Gébler, Clarinettist is realised in the splendid majesty of St Patrick's Cathedral in Dublin. It is a quiet moment and a sublime coda to the film.

Doyle's working method emphasises rewrites and revisions. The filmed rehearsals for his opera give some glimpses into that behind-the-scenes process - the invisible labour, the necessary repetition, the reworking and adjustments, further revisions and more pondering as to when it might finally be finished, and the need to leave out certain elements ("Magic Memory didn't make it into the final opera", as Doyle comments). Moreover, Doyle's approach frequently involves a reconfiguration of his music - the layering of new rhythms and harmonies, creating new work from a re-assemblage. 
Lally's documentary has been well received on the festival circuit. While some might have expected a formally experimental film essay to resonate with Doyle's own style and practice, the film is a fluent and effective introduction to and celebration of the artist and his work. And just as Doyle had to jettison some pieces from the final opera to be reassembled elsewhere at another time, Lally too has found space for some of his extra material via YouTube.

In a way the film's production tells a story about the current state of documentary making in Ireland. Lally produced and directed it through his own production company Instigator Films. "Using my own resources and time I took the film to the stage of a good rough cut and I submitted that cut to Screen Ireland for completion funding", he says. It is worth noting that Screen Ireland only part-funded the project and this is a measure of the wider difficulties in funding traditional feature-length documentary in recent years. While the Arts Council's film policy and funding have developed effectively through building up a range of excellent schemes to encourage formally innovative work, this leaves more "traditional" types of documentary such as this one to find support from Screen Ireland, BAI and/or broadcast television, where pressure of ratings and designated slots heavily determine the commissioning process (although, arguably, Doyle might rate as "a national treasure" within those labels and categories that commissioning agents tend to adopt). Despite the lack of interest from the usual funders, Lally went ahead with the project, funding it mainly from his corporate video commissions. Thus, essentially a labour of love, it involved filming Doyle over ten years, in various concerts and locations. Such self-funding is a growing aspect in the Irish production landscape as - while access to facilities becomes more financially reasonable - a key issue continues to be distribution. If, as Lenny Abrahamson asserts, "Ireland's presence globally is through its culture, that's our strongest identifier" (Keegan), then the distribution of Irish features and documentaries such as Lally's will need increased attention and resources to face the ongoing fragmentation of audiences amid a glut of content on a range of global platforms.

\section{Works Cited}

Dignam, Barbara Jillian. "Music from the Mothership". Journal of Music. 10 December 2018.

12 February 2020. https://journalofmusic.com/criticism/music-mothership

Doyle, Roger. "Biography". 26 February 2020. http://rogerdoyle.com/biography/

Griffin, Nathan. "Director Brian Lally Discusses The Curious Works of Roger Doyle". IFTN. $30 \quad$ October $2019 . \quad 12 \quad$ February 2020. http://www.iftn.ie/news/?act1=record\&only=1\&aid=73\&rid=4293046\&tpl=archnews $\&$ force $=1$

Keegan, Rebecca. "Irish Film Board has growing ambition for its industry after 2016 Oscars". LA Times. 26 March 2016. 14 February 2020. https://www.latimes.com/entertainment/movies/la-ca-mn-irish-film-board-20160327story.html

Profile of Roger Doyle. Contemporary Music Centre Ireland website. 14 February 2020. https://www.cmc.ie/composers/roger-doyle

Stephanie McBride is an academic, broadcaster and critic who writes and lectures on film, media and visual culture. Formerly, Assistant Professor in the School of Communications at DCU, Tutor in arts, literature and film at NYU Tisch School of the Arts, she has also taught in 
Visual Culture at NCAD. Selected publications include The Cinema of Place/The Place of Cinema, Ireland into Film: Felicia's Journey. She has long been a contributor to public discussion of media and visual culture: Intermedia column appeared in The Irish Times; a film and TV columnist with CIRCA Art Magazine, where she also edited a number of issues on film, art education, art and science; and a regular contributor to Irish Arts Review.

stephanie.mcbride@dcu.ie

\section{Memory as Trauma \\ Cellar Door (Viko Nikci, 2018)}

\section{Emma Radley}

Emilie Pine, writing in 2011 about the development of a "remembrance culture" in Ireland at the turn of the twenty-first century in response both to official, state-driven investment in commemoration and memorialisation, and to the increasing anxiety around the revelation of historical institutional abuse, comments that:

We are not who we thought we were, or put another way, we remember ourselves differently now. The consequence of this revisiting the past is that it creates new narratives - alternate and more complex narratives - taking account of memories that were for too long 'forgotten', or sidelined, by Irish history and culture. These new narratives expand the traditionally narrow definition of Irish historical identity, and reconfigure this identity through the framework of remembrance and trauma. (3)

The reconfiguration of identity through the uncovering of traumatic historical memory is at the centre of Viko Nikci's remarkable 2018 film Cellar Door. The story focuses on Aidie (Karen Hassan), a young woman who appears to be stuck in a temporal loop, shifting back in forth in time as she tries to unlock a secret buried in her unconscious. The first scene shows her submerged in a bathtub, with no recollection of how or why she is there. The strap-line of the film, "what's the last thing you remember?", becomes a recurring refrain: in a macabre take on Groundhog Day, Aidie is returned over and over to the same scenes, reliving the loop to find some kind of clue to make sense of her story, and to allow her to progress to the next level of memory.

It quickly becomes clear that the story is about a lost child, taken from her at birth while she is imprisoned in an unnamed institutional setting. We see her pregnant in a church, with a sinister nun, Bly (Catherine Walker), and Kassel, a priest (Mark O'Halloran), offering assistance, shelter, and care. We see her in a circle of other women, under the watchful gaze of the same nun, each steadfastly refusing to speak to her. We see her locked in a small bedroom, drawing the faces of children in her notebook and on the walls. We eventually see her give birth in a dark and windowless room, with the nun and priest dispassionately looking on; we see her screaming as she wakes, with no baby, clutching her flattened stomach. The spectre of Ireland's architecture of containment (a phrase taken from James M. Smith's book on the Magdalen system), the large scale incarceration of young women in church-run (and 
state-endorsed) institutions such as the Magdalen laundries and mother-and-baby homes throughout the twentieth century, haunts the film: indeed, director and screen writer Viko Nikci cites this history in interviews about the film specifically referencing Tuam, where historian Catherine Corless uncovered evidence of the mass burial of the bodies up to 796 infants and children in unmarked underground containers beneath the Bon Seceurs Mother and Baby Home in Tuam, Co. Galway, between 1925 and 1961. The ghost of Tuam is overtly invoked in the script, in a scene where Aidie confronts her mother about her father's awareness of what happened to her baby - "you could fill a septic tank with what he knows", she says bitterly; later, we see her scrabbling in the earth in the garden of the institution, looking for a handle to an underground cavern where she believes her son is located, having been told by another inmate to "follow the pipes". (The maps of the home at Tuam mark the underground container in which the human remains were found as septic tanks, though this is disputed by the order).

Cellar Door does not merely conjure this history as a narrative framework: Ireland's architecture of containment also operates as a formal and an aesthetic frame of reference for the film. The mise-en-scene is eerily familiar: the tiled hallways, claustrophobic stairways, and looming religious statues recall both the photographs of real-life institutions published in media accounts and official reports, as well as the documentary and feature film reconstructions of these spaces. There are visual echoes of Peter Mullan's The Magdalen Sisters and Aisling Walsh's Sinners (both from 2002) in particular, in the disorientating architecture of the convent and the camera's focus on railings, fences, and barred windows. The women trapped with Aidie wear shapeless pinafores resonant of the aprons worn by the women that toiled in the laundries. And yet, while there is a concerted effort to "date" the story within Ireland's "new narrative" of historical trauma, there is also a palpable resistance to fixing the story as something that happened in the past, something which Aidie (and thus Ireland) needs to work through, and thus move on from. The film is imbued with a timeless, dream-like, almost fairy-tale aesthetic, as well as the nightmare of historical reality: Aidie's pre-incarceration costume, for example, evokes the 1950s with its tailored pinstriped dress and Mary Jane shoes, but also brings to mind "Alice in Wonderland" - an effect heightened by the disorientating jump cuts that shift Aidie from one temporal space to another, as if falling down a (rabbit) hole. Catherine Walker's costume also seems to deliberately lack specificity, and feels almost theatrical or cinematic at times - she wears a variety of different habits, ranging from the loose, less structured, headscarf often worn by modern sisters, to the boxy wimple of the Sisters of the Good Shephard (an order particularly associated with the Magdalen system, and the habit used in both Mullan's and Walsh's films), to the more conspicuous starched cornette of the traditional habit of the Daughters of Charity (channelling a more performative aesthetic, à la The Flying Nun). Aidie's lover and the father of her baby is similarly performative, seemingly ripped from the annals of Hollywood 'Oirishness', replete with rustic braces and a flat cap. The group sessions with the other women in the institution have a distinctly modern therapeutic air, an air that also underpins Aidie's individual sessions with Kassel, which are psychoanalytic in their playful, cat-and-mouse verbal jousting. The story then is given a more contemporary and universal feel, making it more difficult for the viewer to achieve a comfortable historical distance from cultural trauma.

It's on the level of form, however, that the film most innovatively engages with the Magdalen history from which its nightmares spring. Pine's discussion of memory and trauma insists strongly on the need not just to remember these hidden and silenced stories from the past, but to develop an "ethical remembrance culture": 
It is important to excavate the past, but ... the past should not be preserved eternally within formal and static structures because this too represents a form of repressing memory. These formal structures must be opened up to air and light, to usher in a full acknowledgement of the past, in order for the trauma to be released, and for the future to be able to 'forget'. What is paramount in the present is to be able to create a positive, and ethical, living remembrance culture. (170)

Central to this more ethical form of remembrance is the notion of bearing witness and the importance of testimony. The driving force of the movements seeking to draw attention to the abuses which underpinned state and religious ideology in Ireland in the twentieth century has overwhelmingly been rooted in the stories of the survivors, and spoken through the voices of the women and children that suffered the abuse, as part of a refusal of the politics of silence that surrounded this system. The destabilised formal structure of Cellar Door mimics this investment in witnessing: Aidie's fragmented memories, dropping in and out of time, experiences repeated but with differing resonances and perspectives, reflects the fragmented nature of the testimonies gathered and collated in official inquiries into institutional abuse such as the Ryan Report (2009) and the McAleese Report (2013), and in oral history and research projects such as Justice for Magdalenes Research. The contingent and unreliable record-keeping by the religious orders and the state, which conspired to obscure and indeed obliterate the real lives and experiences of their victims, is also a tangible and powerful feature of the film, in Aidie's discovery of and subsequent destruction of thousands of hidden files in a secret room (echoing the real-life "accidental" destruction of records in many of these institutions); and, in the drawings she feels compelled to etch on the walls of her cell and in her notebook - hundreds of infants and young children, each with a black " $X$ " scratched over their faces.

Ruth Barton discusses the ways in which mainstream narratives of abuse, including the aforementioned films by Mullan and Walsh, are often invested in a more redemptive closure, allowing a "cathartic release" for the audience, which she notes is inconsistent with the testimonies of survivors themselves, both in how they left the institutions, and the lasting effects of their experiences to the present day (121). The conclusion of Cellar Door is ambivalent in this regard. There is catharsis available for the audience, in that the mystery of what happened to Aidie's son is resolved. The final stitching together of the narrative threads might seem too pat for some viewers, and perhaps takes the wind out of the film's trauma sails somewhat. Again, there's a question of form here, in the way Cellar Door situates itself somewhere between thriller, mystery, and horror, echoing films such as Memento (Nolan 2000), and M. Night Shyamalan-style "twist films", in the way the pieces of the story fall into place in the closing sequences. How this formal catharsis intersects with issues of ethical depiction of trauma is complex, as Kathleen Vejvoda points out in a discussion on the representation of child abuse in contemporary Irish horror cinema, arguing that the juxtaposition of trauma and genre "implies that we do not need to care about or even believe such narratives as history" (49), and that in this form, trauma risks becoming just another scary story. Nevertheless, Vejvoda continues, "there is also a need to imagine ways of coping with that recurring nightmare, particularly at this juncture of Irish history" (49). The uncanniness at the heart of Cellar Door's formal, aesthetic and narrative structures can be seen, perhaps, as engaging with the (re)emergence of a Gothic mode in literature and film in the post-Celtic Tiger period, presenting Ireland as a cultural landscape in crisis, foregrounding anxieties around memory, guilt and accountability, and recovery (in economic, social, and cultural terms). Alternatively then, the film's "twist" can be read as a powerful statement, one 
which speaks to the continuity of Ireland's architecture of containment in the present day, even as the nation professes to have moved on.

\section{Works Cited}

Barton, Ruth. Irish Cinema in the Twenty-First Century. Manchester: Manchester University Press, 2019.

Griffin, Nathan. "IFTN talks with 'Cellar Door' Writer/Director Viko Nikci”. 18 Jan 2019. http://www.iftn.ie/news/?act1=record\&only=1\&aid=73\&rid=4292472\&tpl=archnews $\&$ force $=1$

Pine, Emilie. The Politics of Irish Memory: Performing Remembrance in Contemporary Irish Culture. London: Palgrave Macmillan, 2011.

Smith, James. M. Ireland's Magdalen Laundries and the Nation's Architecture of Containment. Notre Dame, Indiana: University of Notre Dame Press, 2007.

Vejvoda, Kathleen. "Beyond Horror: Surviving Sexual Abuse in Carmel Winters' Snap". Ireland and Cinema: Culture and Contexts. Ed. Barry Monahan. London: Palgrave Macmillan, 2015. 47-56.

Emma Radley is Senior Teaching and Research Fellow at UCD School of English, Drama and Film. She teaches, researches and publishes in the area of Irish cinema and culture, psychoanalysis, and film theory. She is the co-editor, with Claire Bracken, of Viewpoints: Theoretical Perspectives on Irish Visual Texts, published by Cork University Press in 2013.

emma.radley@ucd.ie

\section{Dublin Murders (BBC/RTE/Starz, 2019)}

\section{Sheamus Sweeney}

Dublin Murders was highly anticipated; a high profile, international adaptation of the phenomenally successful series of crime novels by Tana French, the "undisputed queen of Irish crime fiction" (Scanlon). It had the commissioning and developmental weight of Fremantle Media, the BBC, and Ireland's Element Media behind it. It had the prestige writing talent of Sarah Phelps, mostly known for her successful television adaptations of Agatha Christie and Charles Dickens (Harrison). Finally, throw in some of the most acclaimed and high profile Irish acting talent of recent years; Sarah Greene, Tom Vaughan Lawlor, Killian Scott and Conleth Hill, and all of the elements should be in place for a successful, and highly marketable piece of mainstream crime drama with Irish characteristics. How is it then, that Dublin Murders is resolutely less than the sum of its parts?

For a start, it is a drama with an identity crisis. It careers between different tones and genres, trying on each but never settling. Scandi-noir atmospherics? Conventional crime drama tropes? Gothic doppelganger narrative? Cod Celtic myth and ritual? Lynchian 
dissonance? These are all present in some form or other, and while there are moments throughout that work well, none of it ever really coheres into anything more, well, coherent. To put it into modern podcasting parlance; there is no "there", there.

It is a confection that encapsulates the current political economy of television production in a way that makes established arguments about how to define Irish television drama seem archaic. To the extent that it lands on the zeitgeist at all, it is in being ready made for the algorithms that recommend the infinitely interchangeable crime dramas streaming on Netflix and Amazon (and Hulu in the United States). This feeling that it is neither one thing nor the other extends across the production. It is called Dublin Murders, but was largely filmed in Belfast and Newry. So it was filmed in Ireland, but also not, depending on your perspective. Of course, placelessness is not inherently bad, if the fictional locale has a convincing atmosphere. A historic truism for Irish drama right back to Strumpet City has been that its regional specificity does not travel well. If nothing else, the variety of production entities listed above at least guarantees access to international markets. As noted above, the series was commissioned by the BBC and Starz, filmed by Fremantle Media's Euston Films production company, with additional involvement from Element Media. First run broadcast rights went to BBC and RTE in Europe, and to frequent BBC Worldwide collaborator Starz in the US, airing on all three networks between October and November 2019. In each country initial goodwill towards the series tailed off with an apparent drop in ratings after the first episode (see note below). As time went on, real-time reactions on Irish and British social media displayed an often simultaneous mixture of enjoyment and confusion at the increasingly involved and convoluted plotting. In March 2020 it was streaming on Hulu in the US, although given the opaque nature of streaming services ratings, it is difficult to gauge exactly how this availability translates into audience engagement. None of this is to suggest that the series is not watchable, but given the current glut of streamer-driven productions, perhaps this is not enough. There is hardly a dearth of "watchable" drama already out there...

It presents as a mash-up of three or four different dramas, something which is not helped by the uneven writing. Conleth Hill (Superintendent O'Kelly) seems to have been plucked straight from the book of grumpy 1980s police bosses, constantly threatening to bust asses and excise genitals, and generally making resolutely politically incorrect comments. He is Life on Mars's Gene Hunt without the ironic self-awareness of 2006 (when this series is set). The local colour in the Knocknaree housing estate where the murder takes place seems to have been written by someone who thought Mrs Brown's Boys was a work of qualitative sociology. She is all "ah Jaysis" this, and "little hoor" that.

Even after a second viewing it is impossible to identify how much of the problem with the character of Detective Rob Reilly is down to how he is written or how he is played. Central to his arc is a gradual mental breakdown, exacerbated by an unwise sexual encounter. His subsequent actions seem calculated to make him seem unpleasant, although presumably the intent is to encourage viewer empathy with him as a fundamentally damaged person with a self-destructive urge. Unfortunately, because neither writing nor performance succeeds in properly establishing the character in the first place, he just seems to have had a personality transplant that has turned him into a misogynist deserving of a good kicking.

Part of the problem may inadvertently lie with the source material, not so much because of deficiencies in the books themselves, overlong as they are, but in the nature of the Dublin Murder Squad series. The central character in the books is the fictional Squad itself, with only Detective Frank Mackey acting as a sometimes major, sometimes minor recurring character throughout. This suggests an anthology approach should subsequent series go ahead. More importantly, the creative choice to combine two stories with no narrative reason to overlap does not work. The second story, based on French's second novel, The Likeness, is 
undoubtedly the stronger of the two, but is dragged down by association. It seems likely that the choice to structure the series in this way was made to ensure that the two leads occupied comparable amounts of screen time. A more successful approach may have been to separate the series into two standalone stories. Sarah Greene's Detective Cassie Maddox/Lexie Mangan is the most compelling character onscreen throughout the series. Her gothic inflected storyline works better, has more tension and would have benefited from more attention.

Upon its original publication in 2007, Tana French's In the Woods fitted well into the atmosphere of late Celtic Tiger Ireland. It portrayed a community on the margins of the boom, with a motorway being built over an important archaeological site for no discernible reason, and the uncovered but unresolved sins of the past bursting into the present. In 2019 this is no longer the present. The "modern day" events in Dublin Murders are effectively at an analogous historical distance to the events of the mid-1980s. Nobody currently living in Ireland below the age of twenty five has any real memory of the Celtic Tiger, but the drama seems to be speaking to people for whom the reality of 2006 can be presented as a scenesetting shorthand. Another missed opportunity lies in the failure to spot that the events in the pre-history of the narrative resonate far more profoundly across multiple generations now than they might have in 2006.

The tone of the first book, which is largely dependent on the mental turmoil of Rob Reilly, is externalised in this adaptation. The quasi-supernatural background forces in French's novel work because they are understandable in the context of the repressed and unresolved trauma that Rob Reilly is attempting to work through. Two children disappeared without a trace in the 1980s, and Reilly is the only survivor. This does not need supernatural explanation. People who grew up in Ireland in the 1970s and 1980s, and many who did not, know that there are cases of children going missing without a trace; Mary Boyle in Donegal and Philip Cairns in Dublin spring to mind. Similarly there are horrors stretching back to the foundation of the Irish state for which nobody has ever been held properly accountable. As a pervasive atmospheric in French's novel, this works well. Indeed, it is what makes the novel effective in an Irish context. Living in Ireland is already like living on top of a mass grave.

The screenwriter, Sarah Phelps takes another route, foregrounding the supernatural more explicitly. A troubled homeless man connected with the area traverses the motorway route painting the words "HE RISES" on the hoardings that mark the path of its construction. The final, attempted reveal of the historical disappearance gives us high-pitched laughing voices and high winds, collectively experienced, so apparently real. It feels like Twin Peaks badly crossed with early $X$-Files. It feels crass to express the thought but rarely has a story of murdered children seemed so inconsequential.

Dublin Murders is, in current Netflix-inflected parlance, pure content; it is placeless, genre fluid, watchable... and overlong. Both narratives could have been satisfactorily dealt with - subtext, character conflict and all - in half the screen time. It is ironic that it foregrounds both its place and putative genre without embracing either convincingly. One of the strongest elements of the source material, particularly French's first novel, is how deftly she establishes place and time in the prologue:

This summer explodes on your tongue tasting of chewed blades of long grass, your own clean sweat, Marie biscuits with butter squirting through the holes and shaken bottles of red lemonade picnicked in tree houses... This is Everysummer decked in all its best glory. (French 1)

In spite of its BBC pedigree, this is drama by algorithm. It wants to be the pilot episode of Twin Peaks; the murder of a much loved daughter followed by the painfully raw reactions of 
family members. Unfortunately, it really is a case of first as tragedy then as farce. The anguished, primal howl of Laura Palmer's mother in the first episode of David Lynch and Mark Frost's imitated beyond cliché 1990 television drama is unsettling precisely because it disavows then conventional television depictions of grief. Here, the reactions of the Devlin family provoke viewer responses that can only be adequately expressed through meme or gif form. Attempting to channel the atmosphere and genre melding of Twin Peaks, it ends up closer to Midsomer Murders. The death of a popular child acting as the catalyst for a deep dive into the secrets of the wider community is a well-established convention. It is still effective if done well. Here, there seems to be little connection between the death of Katy and any wider narrative. Her popularity is much stated, but there is little evidence of it, or indeed of its opposite.

On a superficial level the second story (based on The Likeness) could almost be a sequel to Donna Tartt's debut novel The Secret History (1992); where the group of selfisolating students go off and live together in a big house as they enter the world of postgraduate studies. Lexie's (Cassie Maddox's doppelganger) slightly outsider status within the group echoes the narrative point of view of that novel's protagonist. It is a shame that this story rarely rises above the level of a subplot to the killing of Katy Devlin. There is an unwanted pregnancy arising from an illicit intra-group affair, intimations of drug use, an unfeasibly large house which has been left to the dominant member of the group, who seems to want everyone to stay forever. Threads are picked up and dropped peremptorily, and the plot resolution seems to be that sending Cassie into this story has been a dreadful mistake, and it needs to be resolved as quickly as possible so she can get back in time to hear the overly expositional confession of Katy's killer, which is needed to make up for a lot of narrative incoherence. A central plank of this incoherence is, incidentally, the recurring appearance of a vulnerable young woman (presumably described in the script as "disposable skanger \#1") from the opening episode, who is manipulated by Reilly and Maddox to inform on her violent partner. It is a far less effective rendering of a similar interaction in the novel, which establishes and explains the bond between the two detectives. Here it just makes them look shady and possibly guilty of malpractice.

Neither the motive nor resolution of the killing of Katy Devlin seem particularly convincing. The same is true with the subordinate storyline, and they do both source novels a disservice. Both murders seem prompted by the threat posed to a collective, whether familial or social, by somebody leaving; Katy to ballet school, Lexie because of the group's toxicity. Therein lies the potential for some in-depth psychological and inter-personal drama, none of which is really explored. (The same motive re-emerges in French's third novel, Faithful Place, so it can safely be described as a recurring theme).

Part of the problem seems to be that what makes Sarah Phelps such a successful translator of Agatha Christie works to her disadvantage here. Christie's books are built around plot mechanics. Nobody really cares about the interior worlds of the characters. Unfortunately, as Tim Goodman (2019) observed in his own review of Dublin Murders, one of the main concerns that readers of the French novels had with their proposed adaptation was that the author of the source material is far more concerned with the interior worlds of her characters than she is with plot or motive. The resolution of her own telling of In the Woods is arguably less than satisfying, but it matters less because that resolution is also less important to the narrative as a whole. Plucked from its context and placed as the resolution of a drama that effectively treats its characters' complex conflicts as a series of personal tics and narrative waypoints, it evokes little more than a shrug.

Little is known so far about the proposed second series, although given the recurring presence of Frank Mackey throughout the books, Tom Vaughan Lawlor is likely to return. 
French's series continues as it begins, as a varied collection of character explorations wrapped in crime novels which, to their credit, largely avoid the pitfalls of formulaic repetition. Unless the decision is made to approach future novels on terms amenable to these characteristics, rather than attempting to create generic streamable drama with Irish characteristics, then the second series will be as unremarkable and forgettable as the first. This is an era of seemingly unstoppable and insatiable drama production, eerily reminiscent of a property bubble in which the inevitable crash is immanent. It would be a supreme irony if a future Dublin Murders episode based on French's ghost estate novel Broken Harbour, itself winds up as a portent of its own future as one of a host of ghost dramas.

As suggested above, a tendency in Irish television drama has been to opt for vague generalities of place, in the interests of exportability, despite the evidence that the most successful dramas of recent years foreground their locales at an almost granular level. The Wire (2002-2008) seems to be an obvious example. Closer at hand, Channel 4's Derry Girls (2018- ) has been uncompromising in its depiction of place, accent and history, with phenomenal success. Even Killian Scott and Tom Vaughan Lawlor's previous pairing in Love/Hate (2010-2014) presented a version of Dublin, albeit as a dystopian hellhole on the city's northside. The reasons for this are too numerous to go into at length, but even contested forms of authenticity are preferable to generic universality. Perhaps the only way to make Irish stories popular and export friendly, is to actually tell stories about Ireland. After all there is nothing more universal than the structures of capitalism, patriarchy and racism which have been riven through the Irish state since before its inception.

\section{Note}

BBC figures are compiled from the British audience research body at https://www.barb.co.uk/viewing-data/fourscreen-dashboard/. First broadcast figures for episode one were approximately 6 million before hovering around 4.75 million for the rest of the series. Starz figures are taken from https://tvseriesfinale.com/tv-show/dublinmurders-season-one-ratings/. First broadcast figures for episode one were approximately 360,000 before slumping to a series low of 176,000 for the second episode. It averaged 240,000 for the remainder of its run.

\section{Works Cited}

French, Tana. In the Woods. Dublin: Hachette, 2007.

Goodman, Tim. "Dublin Murders: TV Review". The Hollywood Reporter. 10 November 2019. 3 March 2020. https://www.hollywoodreporter.com/review/dublin-murdersreview-1253701

Harrison, Ellie. "Sarah Phelps on Dublin Murders, Sexing up Agatha Christie and Removing Ed Westwick from Ordeal by Innocence". Independent. 14 October 2019. 13 March 2020. https://www.independent.co.uk/arts-entertainment/tv/features/sarah-phelpsdublin-murders-agatha-christie-ed-westwick-sexual-assault-ordeal-by-innocencea9154916.html

Scanlon, Anne Marie. "Books: Lady Killers Queens of the Irish Crime Scene". Sunday $\begin{array}{llllll}\text { Independent } & 28 & \text { August } 2014 . & 3 & \text { March }\end{array}$ https://www.independent.ie/entertainment/books/books-lady-killers-queens-of-theirish-crime-scene-30543949.html 
Sheamus Sweeney is an independent scholar who completed his $\mathrm{PhD}$ at $\mathrm{DCU}$ on the representation of Baltimore in the work of David Simon. He has taught social history and television drama at several institutions.

sheamus.sweeney@dcu.ie 